Ethiopian Journal of Environmental Studies \& Management 8(Suppl. 1): 816 - 825, 2015.

ISSN:1998-0507

doi: http://dx.doi.org/10.4314/ejesm.v8i1.9S

Submitted: June 16, 2015

Accepted: October 16, 2015

\title{
UNDERSTANDING PERCEPTION AND ADAPTATION TO CLIMATE CHANGE AMONG COCOA FARMERS IN TROPICAL CONDITION
}

\author{
OGUNSOLA, G.0., ${ }^{1}$ OLUGBIRE, 0.0., ${ }^{2}$ OYEKALE, A.S. ${ }^{3}$ AND *AREMU F.J. ${ }^{4}$ \\ ${ }^{1}$ Department of Agricultural Economics, Bowen University, Iwo, Oyo State, Nigeria \\ ${ }^{2}$ Forest Economics and Extension Services Department, Forestry Research Institute of \\ Nigeria, Oyo State, Nigeria \\ ${ }^{3}$ Department of Agricultural Economics, University of Ibadan, Ibadan, Nigeria \\ ${ }^{4}$ Department of Agricultural Economics, Obafemi Awolowo University, Ile-Ife, Osun State, \\ Nigeria
}

\begin{abstract}
The impact of climate change on agriculture, economy and livelihood of the populations of developing countries and mainly in Sub-Saharan West Africa (SSWA) is no longer a prediction but reality. The impacts of climate change have been found to be heavy on rural farmers whose source of livelihood is mainly from the natural resources in their environment. The farmers' perception and adaptation to the climate change will therefore determine the extents to which they can overcome the challenges posed by climate change. In this research, the coping strategies as well as factors influencing the cocoa farmers' adaptation to climate change in Ondo State, Nigeria was investigated. Data were collected through multi-stage sampling technique. A well structured questionnaire was used to obtain information from 100 cocoa farming households and data were analyzed using descriptive statistics and Ordinary Least Squares (OLS) Regression Techniques. The descriptive analysis revealed that, all the farmers were aware of climate change and they coped with the observed climate changes. The farmers used various adaptation methods which were diversifying into other crops (14.7\%); monitoring of weather change by indigenous knowledge (32.6\%); regular cocoa spraying (50.5\%) and monitoring of weather change through media (24.2\%). Household size (+0.05), farmer awareness of climate change (+0.34) and access to radio information (+0.81) were the key determinants of adaptation of farmers. Educating the farmers through the media to improve awareness of potential benefits of adaptation is an important policy measure. In addition, enhancing farmers' access to extension agents is crucial in improving farmers' awareness of climate change.
\end{abstract}

Key Words: Perception, Adaptation, Cocoa farmers, Climate change

\section{Introduction}

Perception within the concept of this paper is the process of attaining awareness or understanding of the environment by organizing and interpreting sensory information (Aysel, 2010). Human perception of climate change is a complex issue since the underlying problem is a diffuse and a long-lasting process. Some recent studies provide evidence that public perception of climate change may also be affected by different cultures (Aysel, 2010). Perceptions vary from person to person. Different people perceive different things about the same situation (Flemming, 1995). Farmers' ability to perceive climate 
change is a key precondition for their choice to adapt. Adaptation involves adjustment to enhance the viability of social and economic activities and to reduce their vulnerability to climate, including its current variability and extreme events as well as longer-term climate change (Santiago, 2001). Adaptation to climate is the process through which people reduce the adverse effects of climate on their health and wellbeing and take advantage of opportunities that their climatic environment provides. The term adaptation means any adjustment, whether passive, reactive or anticipatory that is proposed as a means for ameliorating the anticipated adverse consequences associated with climate change (Alao, 1999).

In the 1960 s, the cocoa industry played an important role in Nigeria's economic development. But with the discovery of oil in large quantity, the industry took a back seat. According to Sulaiman (2010), Nigeria's cocoa output currently fluctuates between 350,000 and 400,000 tonnes amid various challenges facing the sector, which include ageing farmers and farm trees, among others. Also, according to the World Cocoa Foundation, the number of cocoa farmers worldwide is between five and six million, while between 40 and 50 million people depend on cocoa for their livelihood with an annual world production of three million tonnes. Annual increase in demand for cocoa has been three per cent per year for the past 100 years with $\$ 5.1$ bn as current global market value of annual cocoa. However, the percentage of cocoa that comes from West Africa (Nigeria inclusive) is 70 per cent, as the length of time required for a cocoa tree to produce its first beans (pods) is an average of three years. About 90 per cent of the world cocoa is grown on nearly two million small family farms, the majority with land holdings of two hectares or less (Sulaiman,
2010). A number of reasons have been given for the decline in cocoa production and the inability of cocoa industry to increase output. Some of these reasons include small farm holdings, transportation mode, and unavailability of human labour, low capital and variability in climatic factors among others.

However, Ondo state being the highest cocoa producing state in Nigeria is highly sensitive to variation in climatic factors most especially rainfall, temperature and sunshine. Several views have been expressed about the impacts of irregularity of climate on cocoa production (Abdoellah, 2007), some claimed that rural and poor cocoa farmers are most affected; some asserted that farmers who depend on traditional livelihood system such as farming, fishing and pastoralism are most affected while others have reported that subsistence cocoa farmers are the most affected (Stigter and Baldy, 1993; Oyekale et al., 2009). It is also well known that cocoa production is highly sensitive to changes in climate, from length and intensity of sunshine, to rainfall and water application, soil condition and temperature due to evapo-transpiration effects. It has been reported widely that climate change also plays a major role in altering the development of cocoa pests and pathogens and shifting their interactions. This translates into lower crop yields, which in turn impact farm income and livelihoods (Anim-Kwapong and Frimpong, 2008).

In this light, this study intends to investigate the cocoa farmers' perception and adaptation to changes in climate Ondo State, Nigeria. This is hoped to give a better understanding of how the cocoa farmers' perceive climate changes and their adaptation methods thereby sustaining Nigeria's position in cocoa production among other countries in the tropics. 


\section{Methodology}

Study Area

The study was carried out in Ondo State $\left(7^{\circ} 10^{\prime} \mathrm{N} \quad 5^{\circ} 05^{\prime} \mathrm{E}\right)$ of Southwestern Nigeria. Ondo State is prominent with Cocoa production and has the highest population of Cocoa trees in Nigeria. The State has 18 local government areas and it is about 20,595 ha in land area with population of about $3,440,000$ persons (NPC, 2006).

\section{Source of Data}

Primary and secondary data were used for this study. The primary data were collected through personal interview and administering of questionnaires on cocoa farm household in the study area while the secondary data were obtained from articles, journals, literature and the internet.

\section{Sampling Techniques}

Multistage Sampling technique was used. At first stage, purposive sampling was used by selecting Ile-oluji/Okeigbo local government area because majority of the farmers there are cocoa farmers. Then at the second stage, simple random sampling technique was used through the use of well structured questionnaire to select from six set of villages in the local government study area. Cocoa farmers were randomly selected and interviewed privately. Although, 100 farmers were selected for interview, 16 farmers from Araromi, 45 farmers from Bankemo, 15 from Akinye, 4 from Onipanu, 7 from Leegun and 8 from Ojowo. Only information supplied by 95 respondents was used for analysis. This was due to lack of cooperation from respondents and inconsistency in the information supplied by some of the respondents.

\section{Data Analysis}

Descriptive statistics such as table, frequency counts, percentage, mean and standard deviation were used to analyze the socio-economic characteristics of the respondents and Ordinary Least Square (OLS) Regression Technique was used to examine factors influencing the cocoa farmers' adaptation to climate change in the study area.

\section{Model Specification}

The implicit form of the regression model for adaptation is

$I=\mathrm{a}\left(\mathrm{M}_{1}, \mathrm{M}_{2}, \mathrm{M}_{3}, \mathrm{M}_{4}, \mathrm{M}_{5}, \mathrm{M}_{6}, \mathrm{M}_{7}, \mathrm{M}_{8}\right.$, $\left.\mathrm{M}_{9}, \mathrm{M}_{10}, \mathrm{M}_{11}, \mathrm{M}_{12}, \mathrm{M}_{13}\right)+\mathrm{U}$

Where;

$\mathrm{I}=$ Adaptation to climate change

$\mathrm{M}_{1}=$ Age of the farmer (years)

$\mathrm{M}_{2}=$ Education of the farmer (years)

$\mathrm{M}_{3}=$ Sex/ Gender of the farmer (male/female)

$\mathrm{M}_{4}=$ Household size (number of persons)

$\mathrm{M}_{5}=$ Farming experience (years of farming)

$\mathrm{M}_{6}=\operatorname{Radio}(\mathrm{Yes} / \mathrm{No})$

$\mathrm{M}_{7}=$ Television (Yes/No)

$\mathrm{M}_{8}=$ Mobile phone (Yes/No)

$\mathrm{M}_{9}=$ Farm size (acres)

$\mathrm{M}_{10}=$ Access to extension services (Yes/No)

$\mathrm{M}_{11}=$ Observed climate changes (PCA result)

$\mathrm{M}_{12}=$ Distance to market (miles)

$\mathrm{M}_{13}=$ Farm income (Naira)

$\mathrm{U}=$ Error term

\section{Results and Discussion}

Some socioeconomic characteristics of the farmers sampled during the study are described below.

\section{Gender of Respondents}

As shown in the table $1,83.2 \%$ of the farmers in the study area are males while $16.8 \%$ are females. This reveals that most of the cocoa farmers in the study area are males. Anselm et al (2011) made similar observation in their study on southeast Nigeria. Nweke and Enete (1999) also made similar observation across six countries of sub-Saharan Africa. Bukh 
(1979) reported that men are most often the heads of households in Africa. It was also observed that most of the female cocoa farmers in the study area use labour for their production due to old age and some of them inherited the farm from their husbands.

Table 1: Distribution of farmers by gender

\begin{tabular}{lll}
\hline Gender & Frequency & Score \\
\hline Male & 79 & 83.2 \\
Female & 16 & 16.8 \\
Total & 95 & 100 \\
\hline
\end{tabular}

\section{Age of Respondents}

About $51.6 \%$ of the cocoa farmers in the study area are 60 years and above, $33.7 \%$ of the farmers are within the age limit $41-60$ years while the remaining $14.7 \%$ are in the age limit $20-40$ years (table 2). They were aged about 62 years on the average with the oldest being 120 years and the youngest being 20 years. Majority of the farmers are 60 years and above and about $48.4 \%$ of the farmers were within the economically active age of 60 years. This is contrary to the expectation that as a result of rural-urban migration, farming has been left to the very old. However, with the current high rate of unemployment, young people may have been resorting to farming though older people are still much involved in cocoa production.

Table 2: Distribution of farmers by age

\begin{tabular}{lll}
\hline Age & Frequency & Percentage $(\%)$ \\
\hline$<20$ & 0 & 0 \\
$20-40$ & 14 & 14.7 \\
$40-60$ & 32 & 33.7 \\
$60-80$ & 37 & 38.9 \\
81 and above & 12 & 12.6 \\
Total & 95 & 100 \\
\hline
\end{tabular}

\section{Educational Status of Respondent}

About $34.7 \%$ of the respondents had no certificate to show for their level of education (table 3), while $27.4 \%$ had First School Leaving Certificate. About 16.8\% of them had secondary school certificate, none had Ordinary National Diploma, $6.3 \%$ had NCE, 3.2\% had first degree, and $1 \%$ had $\mathrm{PhD}$. On the average, the respondents had about 6 years of formal education. This is in line with the above observation that unemployment may have driven educated young people back to the farm.

Table 3: Educational status of the respondents

\begin{tabular}{|c|c|c|}
\hline Level of education & Frequency & $\begin{array}{l}\text { Percentage } \\
(\%)\end{array}$ \\
\hline No formal education & 33 & 34.7 \\
\hline Primary education & 26 & 27.4 \\
\hline $\begin{array}{l}\text { Junior Secondary } \\
\text { education }\end{array}$ & 7 & 7.4 \\
\hline $\begin{array}{l}\text { Senior Secondary } \\
\text { education }\end{array}$ & 16 & 16.8 \\
\hline $\begin{array}{l}\text { National Certificate } \\
\text { of Education }\end{array}$ & 6 & 6.3 \\
\hline $\begin{array}{l}\text { Ordinary National } \\
\text { Diploma }\end{array}$ & 3 & 3.2 \\
\hline $\begin{array}{l}\text { Higher National } \\
\text { Diploma }\end{array}$ & 0 & 0 \\
\hline Bachelor degree & 3 & 3.2 \\
\hline Masters degree & 0 & 0 \\
\hline $\mathrm{PhD}$ & 1 & 1 \\
\hline Total & 95 & 100 \\
\hline
\end{tabular}

\section{Household Size}

This study reveals that $17.9 \%$ of the farmers have at most 4 persons in their households (table 4). $18.9 \%$ of farmers have between 9 and 12 persons in their household, $7.4 \%$ of the farmers have household size between 13 and 16, 4.2\% have household size between 17 and 20 . Majority of the farmers have household size between 5 and 8 persons (about $51.6 \%$ ). The average household size was about eight persons with a minimum of one person and a maximum of 20 persons per household. 
Table 4: Distribution of respondents according to household size

\begin{tabular}{lll}
\hline Household size (no of person) & Frequency & Percentage (\%) \\
\hline $0-4$ & 17 & 17.9 \\
$5-8$ & 49 & 51.6 \\
$9-12$ & 18 & 18.9 \\
$13-16$ & 7 & 7.4 \\
$17-20$ & 4 & 4.2 \\
Total & 95 & 100 \\
\hline
\end{tabular}

\section{Farming Experience}

Years of farming experience are important in determining perception and adaptation of farmers. This is because the more experienced a farmer is, the more easily he can perceive climate changes and adapt to these changes. The result obtained from the study as shown in table 5 indicated that $36.8 \%$ of the farmers have about 20 years of experience, $32.6 \%$ of the cocoa farmers have experience between 21 and 40 years, $26.3 \%$ has experience between 41 and 60 years, $3.2 \%$ with experience between 61 and 80 years and only 1 person with experience above 61 years.

Table 5: Distribution of respondent according to years of experience

\begin{tabular}{lll}
\hline Years of experience & Frequency & Percentage \\
\hline $0-20$ & 35 & 36.8 \\
$21-40$ & 31 & 32.6 \\
$41-60$ & 25 & 26.3 \\
$61-80$ & 3 & 3.2 \\
61 and above & 1 & 1.1 \\
Total & 95 & 100 \\
\hline
\end{tabular}

Farm Characteristics of cocoa farmers

\section{Farm Size}

From table 6, The average farm size was about 6.91 acres (2.799hectares) with the largest size about 25acres (10 hectares) and the smallest size about lacre (0.405hectares). Majority of the farmers are with farm size between 1acre and 5 acres. About $33.7 \%$ were with farm size between 6 and 10 acres, $5.3 \%$ between 11 and 15 acres, $6.3 \%$ between 16 and 20 acres and $2.1 \%$ were between 21 and 25 acres. It is assumed that the larger the farm size, the more the farmer would adapt to change in climate parameters. The probable reason for the negative relationship between adaptation and farm size could be due to the fact that adaptation is plot-specific. This means that it is not the size of the farm, but the specific characteristics of the farm that dictate the need for a specific adaptation method to climate change. Thus future research, which accounts for farm characteristics, could reveal more information about factors dictating adaptation to climate change at the farm versus the plot level (Deressa, 2008).

Table 6: Distribution of respondent according to farm size

\begin{tabular}{lll}
\hline Farm size (acres) & Frequency & Percentage \\
\hline $1-5$ & 50 & 52.6 \\
$6-10$ & 32 & 33.7 \\
$11-15$ & 5 & 5.3 \\
$16-20$ & 6 & 6.3 \\
$21-25$ & 2 & 2.1 \\
$>25$ & 0 & 0 \\
\hline
\end{tabular}


Perception of Climate Change Farmers' Awareness of Climate Change

The respondents were asked whether they have heard of and noticed climate changes. About $100 \%$ of the observed cocoa farmers were aware of climate change (table 7). This suggests that all the farmers are aware of climate change. The awareness of climate change problems and potential benefits of taking action is an important determinant of adoption of agricultural technologies (Hassan and Nhemachena, 2008). Maddison (2006) argued that farmers' awareness of changes in climate attributes (temperature and precipitation) is important to adaptation decision making.

Table 7: Distribution of farmers by their awareness to climate change

\begin{tabular}{lll}
\hline Awareness & Frequency & Percentage \\
\hline Yes & 95 & 100 \\
No & 0 & 0 \\
\hline
\end{tabular}

\section{Observed Climate Changes}

Similarly, on the question of whether climate change will affect agriculture, the respondents overwhelmingly (100\%) said yes (table 8). Thirty eight percent of the respondent observed extremely high temperature, $24.2 \%$ noticed extremely low temperature (note that some of the respondent observed more than two of climatic changes). This shows that about 67 farmers noticed changes in temperature in the study area. As shown in the table below about $85.2 \%$ of the farmers noticed too much rainfall, having the highest frequency. Nigerian government already has agencies charged with environmental issues including climate change and they often sensitize the people through radio and television. This may explain the high level of awareness of the respondents.

Table 8: Distribution of respondent by Observed Climate Changes

\begin{tabular}{lcc}
\hline $\begin{array}{l}\text { Observed Climate } \\
\text { change }\end{array}$ & Frequency & Percentage \\
\hline $\begin{array}{l}\text { Extremely high } \\
\text { temperature }\end{array}$ & 34 & 35.8 \\
$\begin{array}{l}\text { Extremely low } \\
\text { temperature }\end{array}$ & 23 & 24.2 \\
$\begin{array}{l}\text { Too much rainfall } \\
\text { Too low rainfall }\end{array}$ & 81 & 85.2 \\
$\begin{array}{l}\text { Delay in rainfall } \\
\text { commencement }\end{array}$ & 38 & 26.3 \\
$\begin{array}{l}\text { Delay in rainfall } \\
\text { stopping }\end{array}$ & 42 & 40 \\
Too stormy rainfall & 45 & 44.2 \\
Too cloudy cover & 36 & 37.4 \\
\hline
\end{tabular}

\section{Respondents' Awareness Score}

About 57 of the respondents scored low and the remaining 38 scored high (table 9). This is done to measure their level of awareness. The score would be our dummy variable for regression. The mean of sums is 5.27. Respondents that observed below 5.27 score low while the ones above 5.27 score high. Low represents 0 and high represents 1 .

Table 9: Distribution of respondents awareness score

\begin{tabular}{lll}
\hline Sum of observed climate change & Frequency & Score \\
\hline $0-5$ & 57 & Low \\
$6-11$ & 32 & High \\
$12-17$ & 4 & High \\
$18-23$ & 1 & High \\
24 and above & 1 & High \\
Total & 95 & \\
\hline Mean of sums $=5.27 ;<5.27=$ low $;>5.27=$ high $;$ low $=0 ;$ high $=1$
\end{tabular}




\section{Adaptation Methods}

About 12 adaptation methods used by the farmers are shown in table 10. Re-spray cocoa and regular cocoa spraying has the highest mean (0.5053) and irrigation with the lowest mean (0.0632) as shown in table 10 . This reveals that averagely most of the farmers adopt Respraying cocoa or regular cocoa spray.

Table 10: Mean and Standard deviation of coping method used by cocoa farmers

\begin{tabular}{lll}
\hline Adaptation methods & Mean & Standard variation \\
\hline Diversify more into other crops & 0.1474 & 0.35635 \\
Diversify into non-farm activities & 0.1263 & 0.33397 \\
Invest in cocoa drying machine & 0.0421 & 0.20189 \\
Monitor weather change by indigenous knowledge & 0.3263 & 0.47135 \\
Re-spay cocoa & 0.5053 & 0.50262 \\
Reduce time interval for cocoa spraying & 0.3158 & 0.46730 \\
Irrigation & 0.0632 & 0.24454 \\
Monitor weather change through media & 0.2421 & 0.43063 \\
Planting of hybrid seeds & 0.4105 & 0.49454 \\
Regular cocoa spraying & 0.5053 & 0.50262 \\
Changing planting and harvesting time & 0.4000 & 0.49250 \\
\hline
\end{tabular}

\section{Determinants of Cocoa Farmer Adaptation to Climate Change}

The result of the analysis in table 11 show that the explanatory power of the specified variables seems to be low (27.9\%) but this is not uncommon in crosssectional analysis. The overall goodness of fit reflected by the $\mathrm{F}$ value of (2.42) was however highly significant at $1 \%$.

Three of the eleven explanatory variables were significant. Household size was positive and highly significant. The influence of household size on use of adaptation methods can be seen from two angles. The first assumption is that households with large family members may be forced to divert part of the labour force to off-farm activities in an attempt to earn income in order to ease the consumption pressure imposed by a large family size (Yirga, 2007). The other assumption is that large family size is normally associated with a higher labour endowment, which would enable a household to accomplish various agricultural tasks. For instance Croppenstedt et al. (2003) argue that households with a larger pool of labour should be more likely to adopt agricultural technology and use it more intensively because they have fewer labour shortages at peak times. Here it is expected that households with large family size to be more likely to adapt to climate change.

Farmers' awareness to climate change was positive and highly significantly related to farmers' adaptation to climate change. The awareness of climate change is a key precondition to farmers' ability to adapt (Hassan and Nhemachena, 2008). Maddison (2006) argued that farmer awareness of change in climate attributes (temperature and precipitation) is important to adaptation decision making. For example, Araya and Adjaye (2001) and Anim (1999) reported that farmers awareness and perceptions of soil erosion problem as a result of changes in climate, positively and significantly affect their decisions to adopt soil conservation measures. Radio as a means of access to information was positive and significantly related to adaptation to climate change. This suggests that farmers' ability to adapt 
to climate change is greatly influenced by the information they receive from radio on the subject matter. Age, Sex, Education, Farming experience and extension services are not significant. This is contrary to various studies on adaptation that suggest positive and high significance (Panin and Brummer 2000; Norris and Bati, 1987;
Igoden et al., 1990; Lin, 1991 and Maddison 2006). They discovered in their studies that these variables increase the chance of adapting to climate change. This study observed that these factors have little or nothing influence on adaptation but these factors affect awareness which invariably influences adaptation.

Table 11: OLS Regression result of determinats cocoa farmer adaptation to climate change

\begin{tabular}{llll}
\hline S/N & Variables & Coefficient & $\mathrm{T}$ \\
\hline 1 & Sex & 0.05763 & 0.19 \\
2 & Age & -0.00022 & -0.03 \\
3 & Education & -0.00435 & -0.19 \\
4 & Farming experience & 0.00335 & 0.40 \\
5 & Radio & 0.81915 & $2.04^{* *}$ \\
6 & Television & -0.28346 & -1.07 \\
7 & Mobile Phone & 0.17431 & 0.53 \\
8 & Farm size & -0.28678 & -1.45 \\
9 & Access to extension services & -0.01369 & 0.01 \\
10 & Household size & 0.05384 & $2.05^{* *}$ \\
11 & Farmers awareness of climate change & 0.33572 & $2.93^{* * *}$ \\
12 & Distance to market & 0.01369 & 0.64 \\
13 & Farmer income & $7.46 \mathrm{e}-07$ & 1.11 \\
\hline
\end{tabular}

Number of observation $=95 ; \mathrm{F}(13,81)=2.42 ;$ Prob $>\mathrm{F}=0.0083 ; \mathrm{R}^{2}=0.2794 ; * * * 1 \%, * * 5 \%, * 10 \%$

\section{Conclusion}

Since climate change is inevitable, cocoa farmer must therefore adapt to these changes so as to sustain and increase their output. It was observed that the most use method of adaptation among cocoa farmers in ile-oluji/Okeigbo is averagely Respraying cocoa or regular cocoa spray. This may be as a result of lack of proper information on other adaptation methods and insufficient funds. Also it was observed that all the cocoa farmer in the study area are aware of climate changes and all of them adapted to the changes using one or more of the adaptation options available to them.

The factors identified to be influencing the perception and adaptation of cocoa farmers include sex, age, education, radio, television, mobile phone, years of experience, access to information (radio), farm size and access to extension agent. The major factors identified to influence adaptation of cocoa farmers include household size, farmer awareness of climate change, farm size and access to information (radio). Thus future research which accounts for farm characteristics could reveal more information about factors dictating adaptation to climate change at the farm versus plot level. It was therefore recommended that adaptation strategies should thus focus on more than just improved water storage, additional irrigation, and new crop varieties. There is the need to look into the indigenous way of adaptation and fine-tune it to fit in into today. Effective policy must also address market imperfections such as access to information, credit, and linking farmers to markets in order to reach small scale subsistence farmers. 
1. Strengthening social networks through farmer to farmer extension is also important.

2. Actions on multiple scales are needed to promote adaptation and additional actors, such as the private sector, NGOs, and the media should become more involved in promoting adaptation.

3. Government should also ensure equal distribution information, credit and incentives to cocoa farmers.

\section{References}

Abdoellah, S. (2007). $\mathrm{CO}_{2}$ Absorptionemission Balance in Cocoa Plantation. Paper submitted to the Directorate General of Estates, Ministry of Agriculture, Republic of Indonesia, for Global Warming Discussion, Jakarta, $3^{\text {rd }}$ December 2007.

Alao, O.S. (1999). The Effects of Agroclimatic Factors on Food Crops Production in Nigeria Department of Agricultural Economics, University of Ibadan, Ibadan ( B.Sc. Thesis)

Anim-Kwapong, G.J and Frimpong, E.B. (2008). "Vulnerability of agriculture to climate change" cocoa research institute of Ghana http://www.nlcap.net/fileadmin/NCA P/Countries/Ghana/

Enete, A.A. and Amusa, T.A. (2010). "Challenges of Agricultural Adaptation to Climate Change in Nigeria: a Synthesis from the Literature", Field Actions Science Reports [Online], Vol. 4: 1-55. http://factsreports.revues.org/678.ss

Araya, B. and Adjaye, J.A. (2001). "Adoption for farm level soil conservation practices in Eritrea" Indian Journal of Agricultural Economics, Vol. 56, pp. 239-252.
Bukh, J. (1979). The Village Woman in Ghana. Centre for Development Research Publications Series 1. Scandinavian Institute of African Studies, Uppsala, Sweden.

Croppenstedt , A., M., Demeke and M.M., Meschi (2003). Technology Adoption in the Presence of Constraints: the Case of Fertilizer Demand in Ethiopia. Review of Development Economics, 7(1): 5870.

Flemming, C (1995). "An instruction manual of practical techniques for facilitating personal change" published by Transformational processing institute 7448 OAK Park Avenue United State framework and priorities. FAO, Rome.

Hassan, R. and Nhemachena, C. (2008). Determinants of climate adaptation strategies of African farmers: Multinomial choice analysis, African Journal of Agricultural and Resource Economics, 2(1): 83-104.

Igoden, C., Ohoji, P. and Ekpare, J. (1990). Factors associated with the adoption of recommended practices for maize production in the Lake Basin of Nigeria. Agricultural Administration and Extension, 29(2): 149-156.

Lin, J. (1991). Education and innovation adoption in agriculture: evidence from hybrid rice in China. American Journal of Agricultural Economics, 73(3): 713-723

Maddison, D. (2006). "The perception of, and adaptation to climate change in Africa" CEEPA Discussion Paper No.10. Centre for Environmental Economics and Policy in Africa, University of Pretoria, South Africa.

National Population Commision (NPC, 2006). Provisional 2006 Nigeria Census Results. 
Norris, E. and Batie, S. (1987) Virginia farmers' soil conservation decisions: an application of Tobit analysis. Southern Journal of Agricultural Economics, 19(1): 89-97.

Oyekale, A.S., Bolaji, M.B. and Olowa, O.W. (2009), The Effects of Climate Change on Cocoa Production and Vulnerability Assessment in Nigeria. Agricultural Journal, 4(2): 77-85.

Santiago, O. (2001). "Vulnerability and adaptation to climate changes concepts and issues, assessment methods".

http://www.cckn.net/pdf/va_foundatio $n \_$final.pdf

Stigter, C.J. and Baldy, C. (1993). Manipulation of the microclimate by intercropping: making the best of services rendered. In: H. Sinoquet and P. Cruz (Eds.), Ecophysiology of tropical intercropping, INRA, Paris/Guadeloupe (French Antilles) (pp. 29 - 44).

Sulaiman, A. (2010). 'Increasing Nigeria's cocoa production' Sunday, $18 \mathrm{Jul}$ 2010 post on NBF topics.

Yirga, C.T. (2007). "The dynamics of soil degradation and incentives for optimal management in Central Highlands of Ethiopia" PhD Thesis. Department of Agricultural Economics, Extension and Rural Development. University of Pretoria, South Africa. 